\begin{tabular}{|l|l|l||}
\hline \multicolumn{2}{|c|}{ PublisherInfo } \\
\hline \hline PublisherName & $:$ & BioMed Central \\
\hline \hline PublisherLocation & $:$ & London \\
\hline \hline PublisherImprintName & $:$ & BioMed Central \\
\hline \hline
\end{tabular}

\title{
Project IMPACT: A database system for measuring and comparing patient outcome
}

\begin{tabular}{|l|l|l||}
\hline \multicolumn{2}{|c|}{ ArticleInfo } \\
\hline \hline ArticleID & $:$ & 4277 \\
\hline \hline ArticleDOI & $:$ & $10.1186 /$ ccf-2000-webreport1282 \\
\hline \hline ArticleCitationID & $:$ & webreport1282 \\
\hline \hline ArticleSequenceNumber & $:$ & 18 \\
\hline \hline ArticleCategory & $:$ & Web report \\
\hline ArticleFirstPage & $:$ & 1 \\
\hline \hline ArticleLastPage & $:$ & 3 \\
\hline \hline & & RegistrationDate : 2000-2-21 \\
\hline ArticleHistory & $:$ & OnlineDate \\
\hline \hline ArticleCopyright & $:$ & Current Science Ltd2000-2-21 \\
\hline \hline ArticleGrants & $:$ & \\
\hline \hline ArticleContext & $:$ & 1305444 \\
\hline \hline
\end{tabular}




\section{Overview}

Project IMPACT is a database system that allows the quantification of practice patterns and patient outcomes as well as comparison with other participating ICUs worldwide (via local and central database components). The Project IMPACT website [part of the Society for Critical Care Medicine (SCCM) website] provides a comprehensive description of the system as well as an FAQ list, downloadable demos of the software and an explanation of the pricing system.

There is also the opportunity to submit research proposals relevant to the science and practice of critical care medicine which would utilise information stored in the central Project IMPACT database. The database has been developed by the SCCM in collaboration with Tri-Analytics Inc.

\section{Content}

The database system would appear to be a necessarily complex piece of software, and in fully explaining the product and extolling its virtues, the site is very densely packed with information. There are a few idiosyncrasies about the site. To access the download section, you first have to fill in an online form and provide details about yourself/your organisation. You also have to select which of the two demos you require, without any information being provided as to what each does, or what the file size is. For the record, both demos are about $1.4 \mathrm{Mb}$. The site also does not contain the latest developments for Project IMPACT. Curiously, the Winter 1999 issue of SCCM's FORUM has a headline stating that Project IMPACT now has 100 participating ICUs, yet this is not mentioned in the Project IMPACT site. There is however, an online form that you can fill in to request an information pack.

This site requires careful reading, and is not really aimed at the casual browser. The site does provide a very detailed synopsis of the power of the database system, and does so without resorting to marketing hype.

\section{Other comments}

November 1999 


\section{Evaluation}

None

\section{References}

1. Project IMPACT. [http://www.sccm.org/pi]

This PDF file was created after publication. 